\title{
FACTORS INFLUENCING LEVEL OF PHYSICAL ACTIVITY AMONG FEMALE STUDENTS FROM THE VISEGRAD COUNTRIES
}

\section{CZYNNIKI WPEYWAJĄCE NA POZIOM AKTYWNOŚCI FIZYCZNEJ STUDENTEK Z PAŃSTW WYSZEHRADZKICH}

\author{
Ewelina Niźnikowska ${ }^{1(B, C, D, E, F)}$, Józef Bergier ${ }^{1(A, E, F, G)}$, Barbara Bergier $^{1(B, D, E, F)}$, \\ Pongrăc Ăcs $^{2(A, F)}$, Jăn Junger ${ }^{3(A, F)}$, Ferdinand Salonna ${ }^{4(A, F)}$ \\ ${ }^{1}$ Pope John Paul II State School of Higher Education in Biała Podlaska, Poland \\ ${ }^{2}$ University of Pécs , Hungary \\ ${ }^{3}$ Pavol Jozef Šafárik University in Košice, Slovakia \\ ${ }^{4}$ Palacký University, the Czech Republic
}

Authors' contribution Wkład autorów: A. Study design/planning zaplanowanie badań B. Data collection/entry zebranie danych C. Data analysis/statistics dane - analiza i statystyki D. Data interpretation interpretacja danych E. Preparation of manuscript przygotowanie artykułu F. Literature analysis/search wyszukiwanie i analiza literatury G. Funds collection zebranie funduszy

\section{Summary}

Background. Our study aims to illustrate the diversity in levels of physical activity among female students from the Visegrad countries (V4), in four domains: job-related activity, transportation physical activity, housework, house maintenance, and caring for family, as well as recreation, sport, and leisure-time physical activity. These domains were correlated with factors including: BMI, field of study, physical fitness self-assessment and amount of leisure time.

Material and methods. In total 1,169 female students from V4 countries: the Czech Republic, Slovakia, Hungary and Poland were involved in the study. In terms of conducting the study, the long version of the International Physical Activity Questionnaire IPAQ, was utilised.

Results. Female students from the V4 countries were characterized by moderate (47.5\%) and high $(43.7 \%)$ levels of physical activity, and the WHO recommendations on health-related quality of life were fulfilled in more than $80 \%$ of the respondents.

Conclusions. Analysis showed statistically significant differences in BMI, where underweight students (59.3\%) demonstrated a moderate level of physical activity. The physical fitness selfassessment of female students from the V4 countries shows significant differences in their level of physical activity in all analysed areas and indicates that field of study as well as their amount of leisure time do not notably affect their level of physical activity.

Keywords: physical activity, female students, IPAQ, V4

\section{Streszczenie}

Wprowadzenie. Celem pracy było ukazanie zróżnicowania poziomu aktywności fizycznej studentek z państw wyszehradzkich (V4) w czterech obszarach tj. w pracy zawodowej/na uczelni, w przemieszczaniu się, w pracach domowych oraz sporcie w zależności od wskaźnika BMI, kierunku studiów, samooceny sprawności fizycznej i ilości posiadanego czasu wolnego.

Materiał i metody. Badaniom poddano 1169 studentek z grupy państw V4: Czech, Słowacji, Węgier i Polski. W pracy zastosowano metodę sondażu diagnostycznego z wykorzystaniem Międzynarodowego Kwestionariusza Aktywności Fizycznej IPAQ - wersja długa.

Wyniki. Studentki państw V4 charakteryzowały się umiarkowanym $(47,5 \%)$ i wysokim $(43,7 \%)$ poziomem aktywności fizycznej, a prozdrowotne rekomendacje WHO spełniło ponad $80 \%$ badanych.

Wnioski. Analiza statystyczna wykazała istotne statystycznie zróżnicowanie w przypadku wskaźnika BMI, gdzie studentki z niedowaga (59,3\%) uzyskały umiarkowany poziom aktywności fizycznej. Samoocena sprawności fizycznej studentek z państw V4 istotnie różnicowała ich poziom aktywności fizycznej we wszystkich analizowanych obszarach, a kierunek studiów oraz ilość posiadanego czasu wolnego nie różnicuje istotnie statystycznie poziomu aktywności fizycznej.
Słowa kluczowe: aktywność fizyczna, studentki, IPAQ, V4
Tables: 1

References: 29

Submitted: 2018 Oct 10

Accepted: 2018 Nov 16 


\section{Introduction}

Physical activity plays an important role in modern society and in the life of each human being. What seems disturbing though is that the amount of daily activity undertaken is reducing.

The studies by Bauman et al. [1] conducted in 20 countries with the help of the International Physical Activity Questionnaire (IPAQ) found that a high level of physical activity was achieved in more than half of the populations in only eight countries. According to the International Prevalence Study on Physical Activity, it appears that the highest percentage of people with a low level of physical activity was reported in Belgium, Japan, Saudi Arabia and Taiwan (40\%). Further, international comparisons show that the least active populations are those in France (43\%), Belgium (40\%) and the United Kingdom (37\%). Sill, according to the WHO World Health Survey reports, physical inactivity is highest in Brazil (over 30\%) and Spain (25\%). When the data from the Central Statistical Office of Poland was analysed, it was noticed that the percentage of Poles with high levels of physical activity is relatively small (28\%) and comparable to that found in other countries i.e. Finland (24\%) and Sweden (33\%), whose inhabitants are generally considered to be highly active [2]. And, although Poles understand the role of physical activity in health and have increasingly attached more importance to regular sporting activities, the analysis of research findings leads to the conclusion that the Polish society actually participate in low levels of physical activity.

The recently observed decrease in physical activity is one of the most important threats to public health, and recent estimates suggest that about 2 million deaths a year worldwide are caused by a lack of physical activity [3].

The analysed survey reports on physical activity show similar trends. Physical activity is more common among men than women. Sport appeals to young people and regular exercise decreases with age. Further, studies indicate that it is the residents of urban rather than rural areas who participate in physical activity, which is largely related to greater accessibility to municipal sports facilities and equipment. Another factor is education, where the number of people who exercise regularly tend also to have higher levels of education [4-6].

The issue of physical activity among female students has been discussed increasingly by both the research community in Poland [7-11] and abroad [12-21]. These publications relate primarily to the assessment of the level of activity undertaken in everyday life, work and leisure time.

The time spent at university is the final stage of formal education during which students can be provided and monitored by large-scale physical activity programme that would ensure a better quality of life. Despite this, most of the activity undertaken by students consists of studying or performing activities of daily living, and with technological advances, the energy expenditure intended for such activity continues to decrease. However, it should be remembered that improperly conducted exercise can cause injury. Therefore, when implementing any health-enhancing physical activity, one should follow expert guidelines. Accordingly, adults aged 18-65 should undertake 30 minutes of moderate physical activity 5 days a week, or 20 minutes of intense physical exercise 3 days a week. It is also recommended that adults undertake weight training 2 days per week [3]. However, despite numerous recommendations issued by health institutions involved in researching physical activity, little effort has been made to educate the public about these guidelines. According to Kay [12], only $36 \%$ of the respondents in the United States were aware of any recommendations on physical activity for health.

Despite numerous studies concerning this particular issue, it seems reasonable to continue to seek data about physical activity among students.

The following article aims to present the existing differences in levels of physical activity among female students from the V4 countries in four essential for humans life domains: i.e. job-related activity, transportation physical activity, housework, house maintenance, and caring for family, as well as recreation, sport, and leisuretime physical activity in regard to BMI, the field of study, physical fitness self-assessment and amount of leisure time.

\section{Material and methods}

The study was conducted in May 2015 and in total it involved 1169 students from the Visegrad countries: the Czech Republic (24.3\%), Slovakia (21.4\%), Hungary (22.6\%) and Poland (31.7\%). 117 surveys were rejected as incomplete. The average age of the respondents was 21.5 . Table 1 . shows the detailed characteristics of the surveyed participants. 
Table 1. Characteristics of the participants

\begin{tabular}{|c|c|c|c|c|c|}
\hline & \multicolumn{4}{|c|}{ Country } & \multirow[b]{2}{*}{ Total $(n=1169)$} \\
\hline & $\begin{array}{c}\text { Slovakia } \\
(n=250)\end{array}$ & Poland $(n=371)$ & \begin{tabular}{|c|} 
Czech Republic \\
$(\mathrm{n}=284)$
\end{tabular} & $\begin{array}{l}\text { Hungary } \\
(n=264)\end{array}$ & \\
\hline \multicolumn{6}{|c|}{ Course of study } \\
\hline humanities courses & $29.2 \%$ & $35.6 \%$ & $32.0 \%$ & $34.1 \%$ & $33.0 \%$ \\
\hline medical courses & $57.6 \%$ & $34.8 \%$ & $37.7 \%$ & $30.7 \%$ & $39.4 \%$ \\
\hline technical courses & $13.2 \%$ & $29.7 \%$ & $30.3 \%$ & $35.2 \%$ & $27.5 \%$ \\
\hline \multicolumn{6}{|c|}{ BMI Index } \\
\hline underweight & $13.2 \%$ & $14.1 \%$ & $13.7 \%$ & $11.0 \%$ & $13.2 \%$ \\
\hline healthy weight & $75.2 \%$ & $72.4 \%$ & $73.6 \%$ & $76.8 \%$ & $74.2 \%$ \\
\hline overweight & $11.6 \%$ & $13.5 \%$ & $12.7 \%$ & $12.2 \%$ & $12.6 \%$ \\
\hline \multicolumn{6}{|c|}{ Self-assessment of physical fitness } \\
\hline high & $12.5 \%$ & $7.8 \%$ & $8.0 \%$ & $21.3 \%$ & $11.9 \%$ \\
\hline medium & $74.6 \%$ & $76.8 \%$ & $77.5 \%$ & $66.5 \%$ & $74.2 \%$ \\
\hline low & $12.9 \%$ & $15.4 \%$ & $14.5 \%$ & $12.2 \%$ & $13.9 \%$ \\
\hline \multicolumn{6}{|c|}{ Amount of leisure time } \\
\hline sufficient & $43.3 \%$ & $55.0 \%$ & $52.5 \%$ & $29.7 \%$ & $46.2 \%$ \\
\hline insufficient & $48.9 \%$ & $43.7 \%$ & $44.6 \%$ & $62.0 \%$ & $49.2 \%$ \\
\hline no leisure time & $7.8 \%$ & $1.4 \%$ & $2.9 \%$ & $8.4 \%$ & $4.7 \%$ \\
\hline
\end{tabular}

The research was carried out in 2015 as part of the Standard Grant programme of the International Visegrad Fund. The project "Physical and recreational activity and nutrition of youth from the Visegrad countries" aimed to integrate scientists from partner universities in the Czech Republic, Poland, Slovakia and Hungary by enabling them to conduct research together and exchange their own experiences and knowledge.

The study involved a diagnostic survey utilizing the International Physical Activity Questionnaire IPAQ - the long version, which allowed us to analyse physical activity in different areas of human life (job-related activity, transportation physical activity, housework, house maintenance, and caring for family, as well as recreation, sport, and leisure-time physical activity). The questionnaire's core questions were supplemented with those concerning the data on height and weight, which enabled us to calculate the participant's Body Mass Index (BMI), as well as information on the field of study, physical fitness self-assessment and amount of leisure time. In the presented analysis, the level of physical activity was assessed on the basis of the MET indicator (Metabolic Equivalent of Task), which informs us about the individual metabolic rate change during an exercise compared to the same change at rest. Basing on the study findings, the researcher concluded that the surveyed persons could be classified according to their level of physical activity. Three levels of activity were distinguished: high, moderate and low [9]:

1. High - the category comprises people who meet one of the following criteria:

-3 or more days of intense physical effort, a total of at least 1,500 MET min./week,

- 7 or more days of any combination of efforts (walking, moderate or intense efforts) exceeding 3000 MET min./week.

2. Moderate - the category involving those who meet one of the following three criteria:

- 3 or more days of intense physical effort, no more than 20 minutes a day,

- 5 or more days of moderate effort or walking, no more than 30 minutes a day,

- 5 or more days of any combination of physical activity (walking, moderate or intense exercise) exceeding 600 MET min./week.

3. Low - the category consisting of those persons who did not show any physical activity or did not meet the conditions for high and moderate levels.

The statistical data analysis was done by STATISTICA V.10. To detect statistically significant we used the Chi-square test of independence for quality features. To check for statistically significant differences in the level of total physical activity and its areas (domains) due to the amount of available leisure time, the level of physical fitness self-assessment, the course of study and BMI, an arithmetic mean was calculated using the nonparametric Kruskall-Wallis test. If any significant differences were found, the post-hoc U Mann-Whitney test was used to examine which variables were involved. In all the analysed cases, the significance level was assumed at $\mathrm{p}=0.05$. 


\section{Results}

The most commonly used measure to provide an idea of one's figure is the BMI index. It is the quotient of body mass (in kilograms) and square of body height (in meters). The index allows to determine insufficient weight and overweight. In case of adults (over 18 years old), it assumes the value below 18.5 to indicate body mass deficiency, 18.5 to 24.99 - norm and over 25 - overweight [22]. When BMI was correlated with the level of physical activity in female students from the V4 countries, it was found that underweight persons showed the highest level of overall activity (5478.5 MET. min./wk.), job-related physical activity (1772.5 MET. min./wk.), and transportation physical activity (1188.7 MET. min./wk.). Normal-weight students demonstrated the highest level of recreation, sport, and leisure time activity (1515.7 MET. min./wk.), whereas those who were overweight engaged in the highest level of housework, house maintenance and caring for family activity (1234.1 MET. min./ wk.). The statistical analysis showed no significant impact of BMI on physical activity levels of the surveyed female students in any of the tested area (Figure 1).

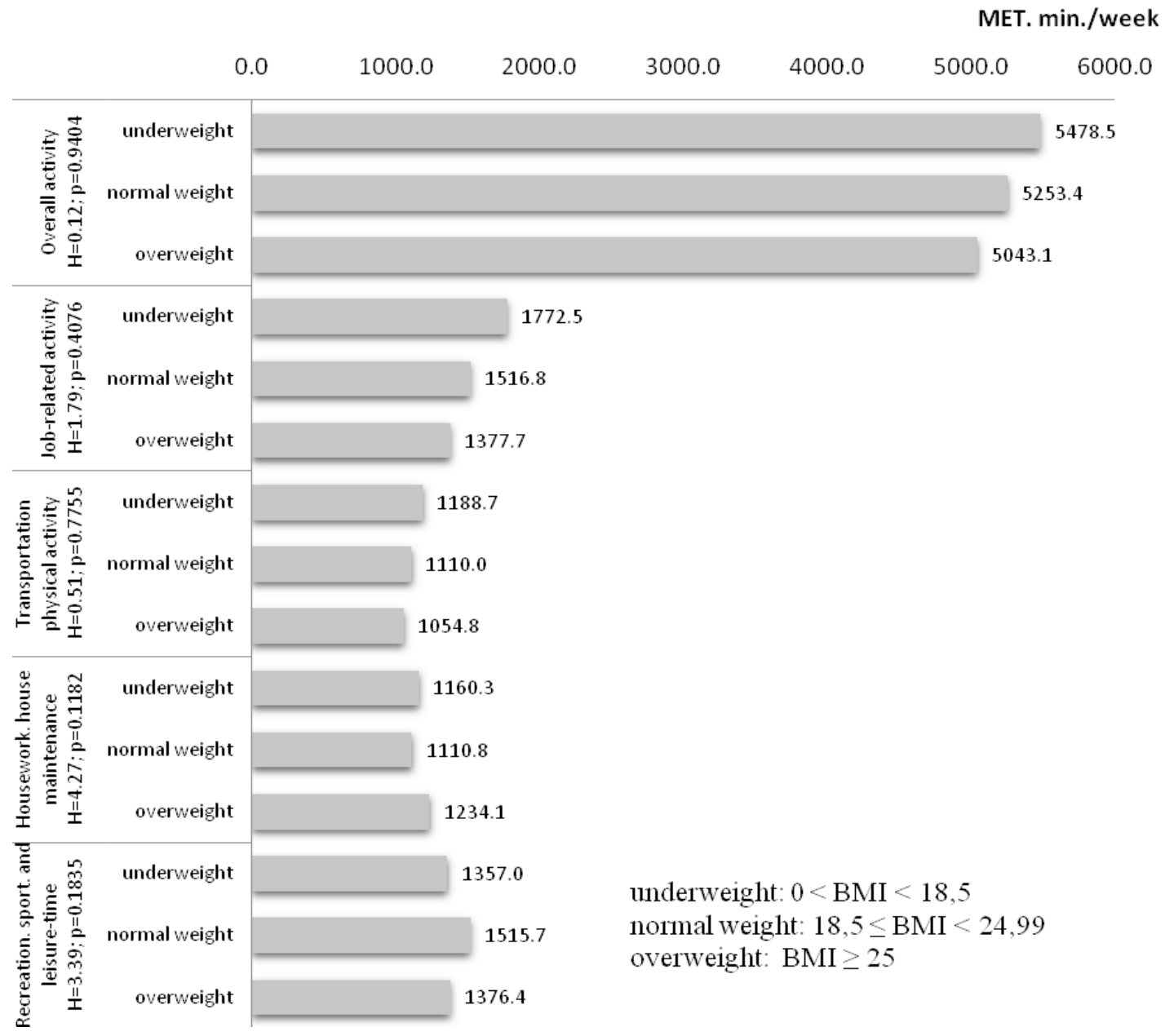

$\mathrm{H}$ - value of the Kruskal-Wallis test

Figure 1. Level of physical activity and its domains in comparison to the BMI of female students

When the impact of the course of study on the level of physical activity was analysed, it was found that the overall physical activity levels of female students of humanities and medical sciences were similar, which amounted to 5278.6 MET. min./wk. and 5271.3 MET. min./wk. respectively. The female students studying humanities demonstrated the highest level of physical activity in two areas: housework, house maintenance and caring for family, as well as recreation, sport and leisure time while, in the other two areas, i.e. job-related physical activity and transportation physical activity, the medical science female students undertook more activity. The lowest level of overall physical activity was recorded among the female technical sciences students (4969.6 MET. min./wk.). Statistical analysis did not show any significant influence of the course of study on the physical activity levels of the surveyed students in any particular area (Figure 2). 


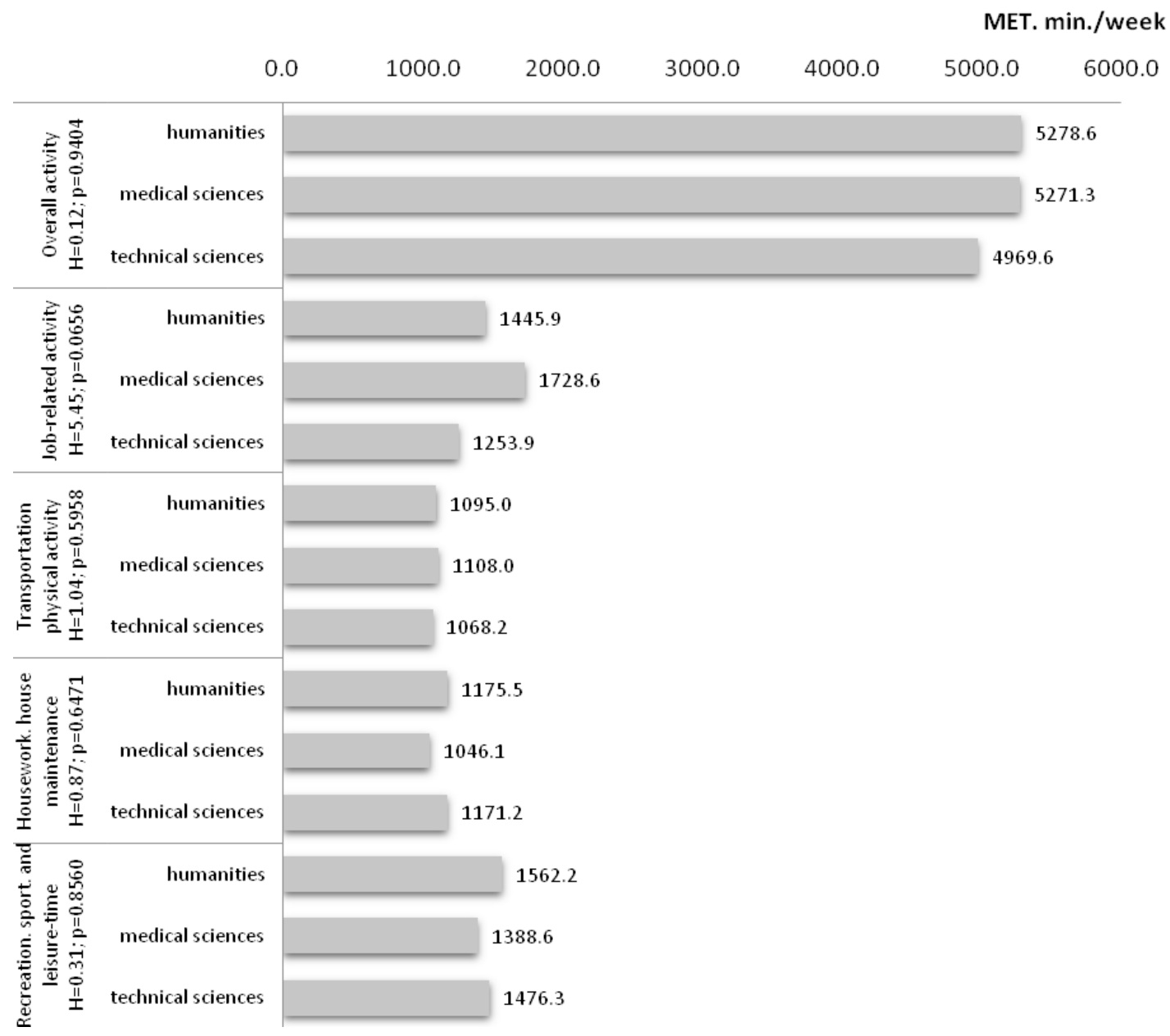

$\mathrm{H}$ - value of the Kruskal-Wallis test

Figure 2. Level of physical activity and its domains in comparison to the female students' course of study

In contrast to the previously presented determinants of physical activity, in the case of physical activity self-assessment, the analysis showed a statistically significant effect of physical fitness self-assessment on the respondents' level of physical activity in all areas. In every case, the female students who evaluated their fitness level as low achieved significantly lower results in the overall level of physical activity than those with high and moderate self-esteem. Additionally, in the case of two activity domains, i.e. overall activity as well as recreation, sport, and leisure-time physical activity, there was observed a significantly higher activity level in female students with high physical fitness self-esteem not only in relation to those with low self-esteem but also in relation to the respondents with a moderate physical fitness self-esteem (Figure 3). 


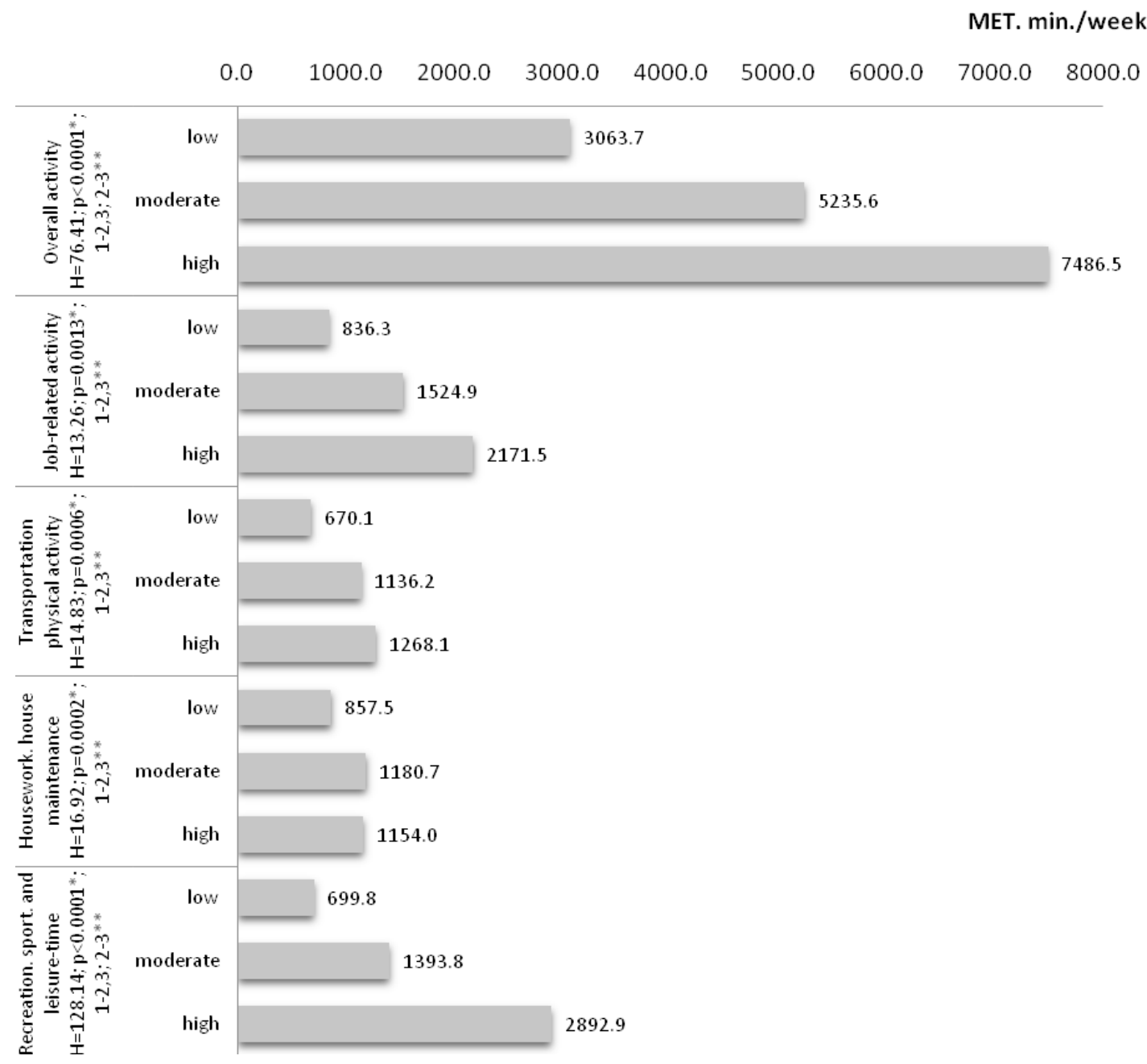

$\mathrm{H}$ - value of the Kruskal-Wallis test

* - significant differences at $\mathrm{p}<0.05$

** - levels of physical fitness self-assessment between which there is statistically significant differences in the MannWhitney U post hoc test; 1-low, 2-moderate, 3-high

Figure 3. Level of physical activity and its domains in comparison to the level of physical fitness self-assessment of female students

Another significant factor in our research was analysing the impact of the amount of leisure time on female levels of activity. The lowest level of overall activity was visible in students lacking leisure time (4502.2 MET. min./wk.), who achieved the highest level only in the area of sport (1646.5 MET. min./wk.). In contrast, the highest level of overall activity was shown by students having little leisure time (5277.8 MET. min./wk.). It seems that job-related physical activity and activity involved in housework, house maintenance and caring for family had the greatest impact on this factor. The statistical analysis showed a significant effect of the amount of leisure time on physical activity levels only in the area of transportation physical activity $(p=0.0395)$, at the expense of those who did not have leisure time (694.3 MET. min./wk.), and in favour of those with a sufficient amount of leisure time (1155.7 MET. min./wk.) (Figure 4). 


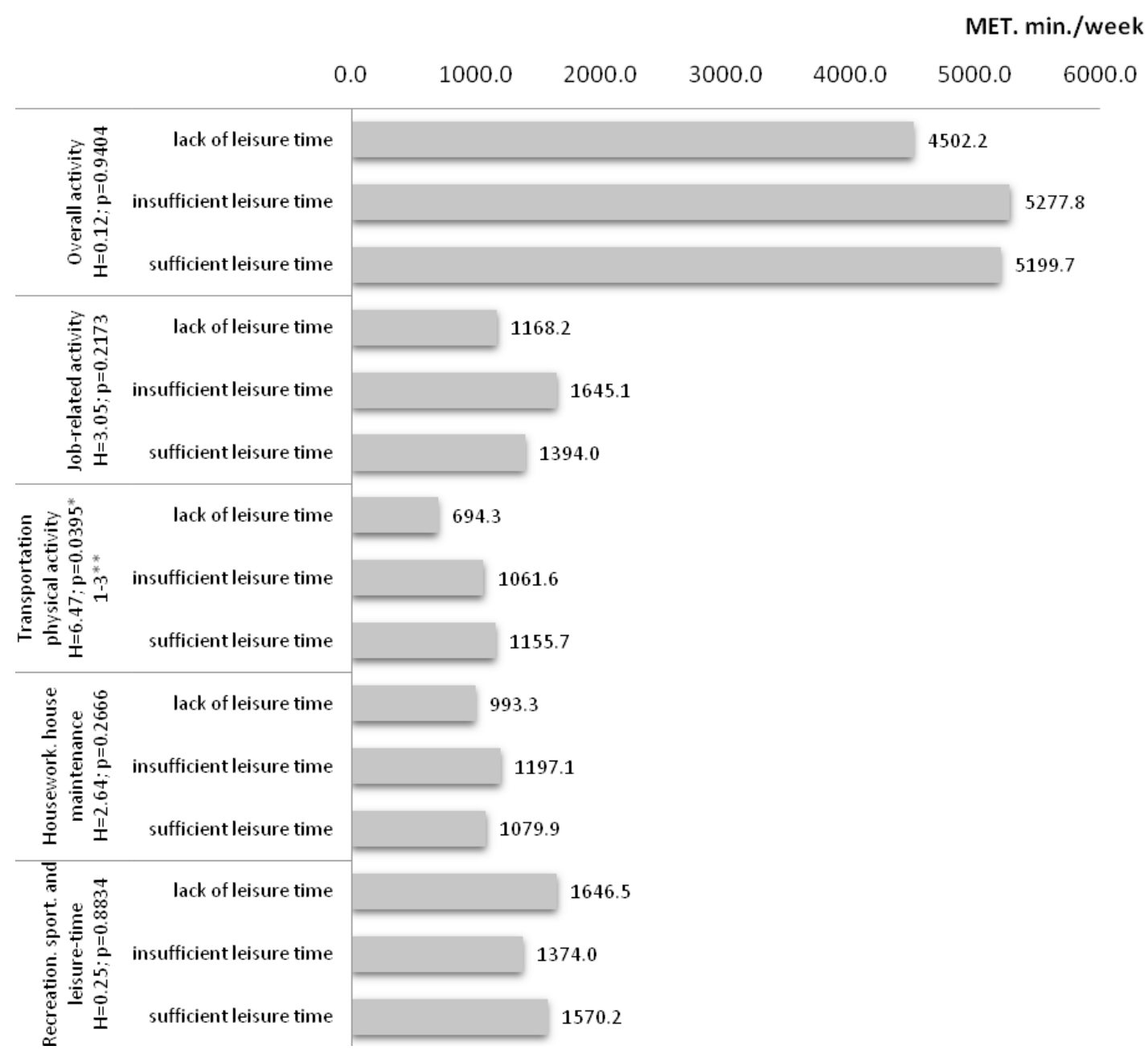

$\mathrm{H}$ - value of the Kruskal-Wallis test

* - significant differences at $\mathrm{p}<0.05$

** - amounts of leisure time between which there is a significant statistical variation in Mann-Whitney U post hoc test; 1-low, 2-moderate, 3-high

Figure 4. Level of physical activity and its domains in comparison to female student leisure time

Most of the surveyed female students showed an average (47.5\%) and high (43.7\%), level of physical activity. The statistical analysis revealed statistically significant differences in the case of BMI ( $p=0.0343)$, where as many as $59.3 \%$ of underweight persons achieved a moderate level of physical activity and physical fitness selfassessment $(p<0.0001)$, where a rise of self-assessment from low, through moderate to high has increased the physical activity in female students from a high level of $17.0 \%$ to $44.9 \%$, and ultimately to $67.7 \%$. When the other factors, i.e. courses of studies and the amount of leisure time are taken into account, the statistical analysis showed no significant differences in the level of students' physical activity (Figure 5). 


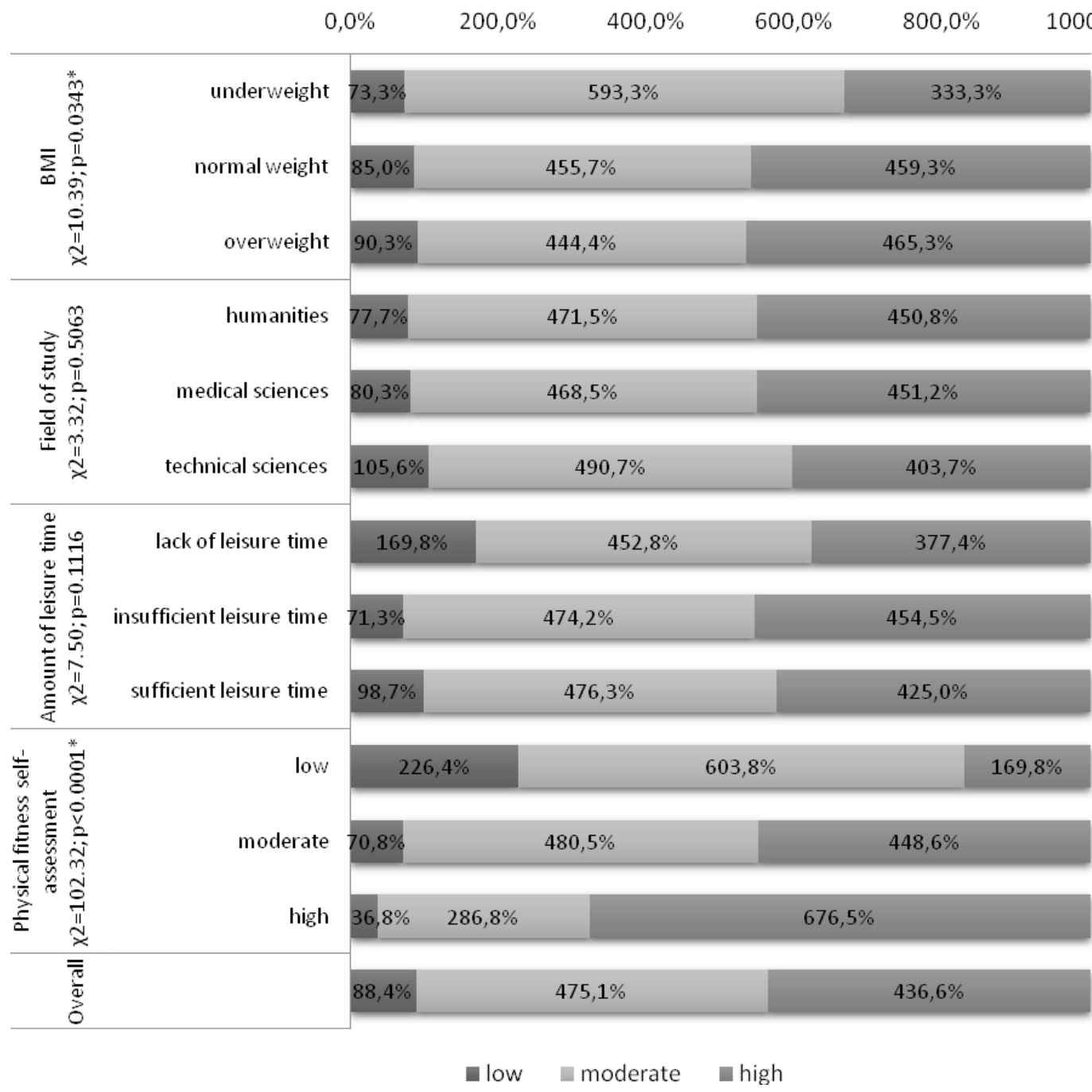

$\chi 2$ - Pearson's chi squared test

* - significant differences at $\mathrm{p}<0.05$

Figure 5. Level of physical activity in students in comparison to the selected domains

Physical activity measured in the domain of recreation, sport and leisure time indicated that $80.7 \%$ of the surveyed female students from the V4 countries meet the latest WHO recommendations on the health-related amount of physical activity (Figure 6). The group consisted of persons who reported at least $150 \mathrm{~min}$./wk. of moderate effort, or at least $75 \mathrm{~min}$./wk. of vigorous effort or cumulative efforts (vigorous and moderate levels) lasting for at least 10 minutes. The remaining respondents, i.e. nearly $20 \%$, did not meet these criteria.

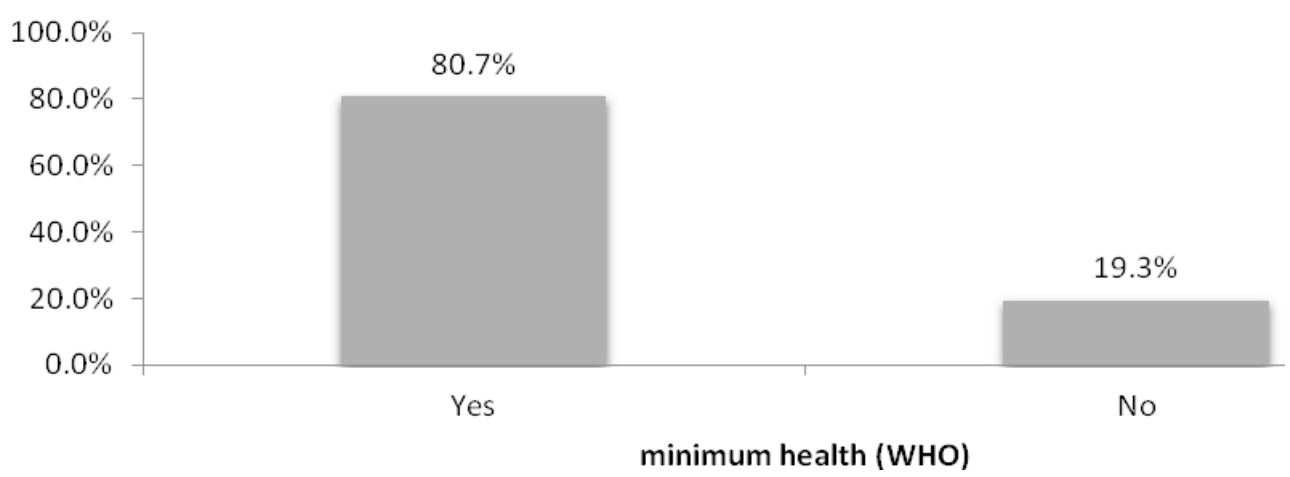

Figure 6. Percentage of female students from V4 countries achieving the minimum requirement of physical activity for health according to the WHO 


\section{Discussion}

The research findings presented in the work show different levels of physical activity for different domains among female students' life in the V4 countries with regard to BMI, field of study, physical fitness self-assessment and amount of leisure time. In order to achieve the objectives of this study, the long version of the International Physical Activity Questionnaire (IPAQ) was used.

What seems worth noting was that the majority of the surveyed female students from V4 countries showed a moderate (47.5\%) and high (43.7\%) level of physical activity. However, different test results were obtained by Guven, Ozcan, Tasgin and Arslan [23], who observed a lower level of physical activity among Turkish female students. A high level of physical activity was visible only in $24.9 \%$ of the respondents, while moderate and low in $44.9 \%$ and $30.2 \%$ respectively.

Nevertheless, high and moderate levels of physical activity effectively lowered the proportion of students with abnormal body weights. Among the female students from the V4 countries, only every fourth was seen as underweight or overweight. When compared to the European populations, this seems to be a very positive finding, since the percentage of obese women in Poland is estimated to have reached 15.2\%, which ranks our country below the average for the European Union female population, i.e. (16.5\%) [24]. Furthermore, the studies indicated that there is a statistically significant statistical variation with regard to BMI, where as many as $59.3 \%$ of the underweight population obtained a moderate level of physical activity. This is confirmed by the research findings conducted by Lipecki Lic and Kukla [25], who analysed the data on physical activity in relation to BMI in female students of the University of Economics in Krakow, and who found that women with lower body weight showed a higher average level of physical activity. Thus, it can be assumed that, to some extent, the obtained findings indicate that physical activity plays a vital role in maintaining proper energy balance in the body.

Another important element in achieving the objective of the study was obtaining information on different levels of physical activity in female students from the V4 countries, with regard to their field of study. A similar level of overall physical activity, i.e. $45.1 \%$, was observed in female students in humanities and medical sciences. The study also confirmed that humanities and medical sciences students exhibited higher levels of physical activity than those doing technical studies courses (10.6\%). Similar findings were reported by Mędrela-Kuder [26], who surveyed Polish female students in medical and technical computing universities in Cracow. She proved that female students studying humanities had more positive attitudes towards physical activity than the ones attending technical computing courses. Slightly different data were obtained in the study conducted in India. A high level of physical activity was seen in almost every third female student of medical sciences (32.9\%), and a low level of activity in one - in every fifth (16.8\%) [27].

When physical activity levels were tested in regard to physical fitness self-assessment, it was found that the highest levels of physical activity were represented by the female students with high physical fitness self-esteem (67.7\%), which indicates that they were fitter when compared with the female students of the Medical University of Lublin [28] and the University of Economics in Krakow [25].

When considering physical activity, one remember that activity is largely determined by the amount of leisure time one has. Based on the analysis of the survey findings, one may say that the lowest level of physical activity was visible in female students from the V4 countries who did not possess much leisure time (17\%). Numerous scientific studies point to the fact that the primary reason for lack of physical activity was a deficit of time -it was this factor that most Poles pointed to when justifying their low physical activity [2]. Further, the research findings obtained by Biernat [9] indicate a low level of activity undertaken in leisure time. According to the author, it does not bode well for Poles, because technological advances and society trends increasingly deprives people of opportunities to exercise and undertake physical work.

The conducted research indicates that the pro-health recommendations issued by the WHO are met by more than $80 \%$ of the female students from the V4 countries. In the UK, only $43.8 \%$ of the population (age $35.3 \pm 10.4$ years) declare participation in recreational activities while in the Netherlands - 48.5\% (age $32.7 \pm 10.9$ years) [29], which is surprising as these countries are known for being very active in this respect and, additionally, their respondents are younger.

The research findings collected by numerous authors show that, although in recent years physical activity increased, it is still sporadic and unsystematic [2]. This finding is all the more important as, when chosen consciously and undertaken habitually, physical activity can become a pillar of human health. Thus, more effort should be put into educating the public on the physical activity guidelines and raising young women's awareness about their significance in health preservation. 


\section{Conclusions}

The analysis of the survey findings leads to the following conclusions:

1. Female students from the V4 countries demonstrated moderate (47.5\%) and high (43.7\%) levels of physical activity; thus, health-related recommendations issued by the WHO are met by more than $80 \%$ of the respondents.

2. The statistical analysis showed significant statistical differences in the BMI index, as a higher level of physical activity was achieved in females with healthy BMI index and overweight and lower in those with lower level of physical activity.

3. Self-evaluation of physical fitness in female students from V4 countries significantly impacts their level of physical activity in all analysed areas.

4. The field of study and the amount of leisure time do not impact significantly on levels of physical activity.

\section{Acknowledgements}

The research was conducted under the project: Physical activity and recreation, and nutrition of young people from the V4 countries, co-financed by the Visegrad Fund, award number 21420053.

\section{References:}

1. Bauman A, Bull F, Chey T, Craig CL, Ainsworth BE, Sallis JF, et al. The international prevalence study on physical activity: results from 20 countries. International Journal of Behavioral Nutrition and Physical Activity. 2009; 6(21). https://doi.org/10.1186/1479-5868-6-21

2. GUS. [Participation of Poles in sport in 2008] [Internet]. Warszawa: GUS [cited 2016 Nov 23]. Available from: http://stat.gov.pl/cps/rde/xbcr/gus/kts_Uczestnictwo_pol_w_sporcie_w-2008r.pdf (in Polish).

3. World Health Organization. Global recommendations on physical activity for health [Internet]. Geneva: World Health Organization; 2010 [cited 2016 Nov 23].

Available from: http://whqlibdoc.who.int/publications/2010/9789241599979_eng.pdf

4. European Commission. The EU guidelines on physical activity. Recommended policy actions in support of health-enhancing physical activity [Internet]. Brussels: European Commission; 2008 [cited 2016 Dec 27]. Available from: http://ec.europa.eu/sport/documents/pa_guidelines_4th_consolidated_draft_pl.pdf.

5. [Conclusions of the Council and the Representatives of the Governments of Member States, meeting within the Council on November 27, 2012, on promoting health-enhancing physical activity (2012), Journal of Laws UE C 393/07] [Internet]. 2012 Dec 19 [cited 2016 Dec 28].

Available from: http://eur-lex.europa.eu/LexUriServ/LexUriServ.do?uri=0J:C:2012:393:0022:0025:PL:PDF (in Polish).

6. American College Health Association. American College Health Association National College Health Assessment II: reference group executive summary fall 2011 [Internet]. Baltimore: American College Health Association [cited 2016 Dec 28]. Available from: http://www.achancha.org/reports_acha-nchaii.html

7. Biernat E, Piątkowska M. WHO recommendations on physical activity for health and recreational activity of Poles. Sports Medicine. 2013; 4(4): 255-264.

8. Piątkowska M. Participation of Poles in physical activity compared to other European Union countries. In: Buśko K., editor. Modern methods of research activity, fitness and human performance. Warszawa: Akademia Wychowania Fizycznego w Warszawie; 2010.

9. Biernat E. [Physical activity of inhabitants of Warsaw. A study of some professional groups]. Warszawa: Szkoła Główna Handlowa; 2011 (in Polish).

10. Topolska M, Sapuła R, Topolski A, Maciejewski M, Marczewski K. [Physical activity and health in women aged 19 to 65 in various walks of life]. Zamojskie Studia i Materiały. 2011; 1(34): 27-36 (in Polish).

11. Bergier J. Physical activity of society - a contemporary issue (an overview of the research). Human and Health. 2012; 6(1): 3-12.

12. Kay MC, Carroll DD, Carlson SA, Fulton JE. Awareness and knowledge of the 2008 physical activity guidelines for Americans. Journal of Physical Activity and Health. 2014; 11: 693-8. https://doi.org/10.1123/jpah.2012-0171

13. Pan SY, Cameron C, Desmeules M, Morrison H, Craig CL, Jiang X. Individual, social, environmental, and physical environmental correlates with physical activity among Canadians: a cross-sectional study. BMC Public Health. 2009; 9(21): 1-12. https://doi.org/10.1186/1471-2458-9-21

14. Gunnell KE, Crocker PR, Mack DE, Wilson PM, Zumbo BD. Goal contents, motivation, psychological need satisfaction, well-being and physical activity: a test of self-determination theory over 6 months. Psychology of Sport and Exercise. 2014; 15: 19-29. https://doi.org/10.1016/j.psychsport.2013.08.005 
15. Downes L. Physical activity and dietary habits of college students. The Journal for Nurse Practitioners. 2015; 11(2): 192-198. https://doi.org/10.1016/j.nurpra.2014.11.015

16. Majeed F. Association of BMI with diet and physical activity of female medical students at the University of Dammam, Kingdom of Saudi Arabia. Journal of Taibah University Medical Sciences. 2015; 10(2): 188-196. https://doi.org/10.1016/j.jtumed.2014.11.004

17. Ács P, Melczer C, Sávolt-Szabó T, Welker Z, Gyúró M, Baumann P, et al. Physical activity of social and professional groups. Health Prob Civil. 2017; 11(3): 150-157. https://doi.org/10.5114/hpc.2017.70005

18. Tsos A, Kasarda O, Pantik V. Female students at higher educational institutions in Ukraine and their level of physical activity. Health Prob Civil. 2017; 11(3): 158-162. https://doi.org/10.5114/hpc.2017.70004

19. Breitenbacha Z, Raposa B, Szabóa Z, Polyák É, Szűcs Z, Kubányi J, et al. Examination of Hungarian college students' eating habits, physical activity and body composition. European Journal of Integrative Medicine. 2016; 8(Suppl. 2): 13-17. https://doi.org/10.1016/j.eujim.2016.11.007

20. Diehl K, Hilger J. Physical activity and the transition from school to university: a cross-sectional survey among university students in Germany. Science \& Sports. 2016; 31: 223-226. https://doi.org/10.1016/j.scispo.2016.04.012

21. Norazlin A, Norshahizat M. University recreational facilities service quality and students' physical activity level. Procedia - Social and Behavioral Sciences. 2016; 224: 207-212. https://doi.org/10.1016/j.sbspro.2016.05.443

22. World Health Organization. Physical status: the use and interpretation of anthropometry. Report of the WHO Expert Committee. WHO Technical Report Series. Geneva: World Health Organization; 1995. No. 854.

23. Guven DS, Ozcan T, Tasgin 0, Arslan F. The relationship between health college students physical activity status and life satisfaction. International Journal of Academic Research. 2013; 5: 327-331. https://doi.org/10.7813/2075-4124.2013/5-4/B.48

24. OECD. Education at a glance 2012: highlights. Paris: OECD Publishing; 2012.

25. Lipecki K, Lic Ł, Kukla P. Levels of physical activity and physical ability and their correlation to the Body Mass Index (BMI) in female students of Tourism and Recreation at Cracow University of Economies. Journal of Tourism and Recreation. 2015; 12: 29-36.

26. Mędrela-Kuder E. Evaluation of the lifestyle of students of physiotherapy and technical \& computer science basing on their diet and physical activity. Annals of the National Institute of Hygiene. 2011; 62(30): 315-318.

27. Padmapriya K, Krishna P, Thennarasu T. Prevalence and patterns of physical activity among students in Bangalore, India. Electronic Physician. 2013; 5(1): 606-610.

28. Kotwica A, Majcher P. Physical fitness level of $1^{\text {st }}$ year medicine and physiotherapy students of Lublin Medicine University. Polish Journal of Sport and Tourism. 2012; 19: 107-118. https://doi.org/10.2478/v10197-012-0011-4

29. Rosenberg DE, Bull FC, Marshall AL, Sallis JF, Bauman AE. Assessment of sedentary behaviour with the International Physical Activity Questionnaire. Journal of Physical Activity \& Health. 2008; 5(1): 30-44. https://doi.org/10.1123/jpah.5.s1.s30 